\title{
ENTREPRENEURSHIP AS THE BASIS FOR THE DEVELOPMENT OF RURAL COMMUNES IN EASTERN POLAND
}

\author{
Andrzej Pawlik', Paweł Dziekański²
}

\begin{abstract}
Reducing development disparities between municipalities requires the development of entrepreneurship, which is an organized process of actions. Entrepreneurship is an interdisciplinary concept that is important for social and economic development. The aim of the article is to assess the entrepreneurship in the aspect of rural communes' development using a synthetic measure. The assessments were carried out in a system of 484 rural communes of voivodships of eastern Poland. Data from the Local Data Bank of the Central Statistical Office of 2009 and 2018 were used as source material. In 2018, the TOPSIS method for measuring entrepreneurship ranged from 0.07 to 0.63 and the development measure from 0.23 to 0.62 . This confirmed the smaller diversity of rural communes in eastern Poland in the aspect of development, and greater in the aspect of entrepreneurship. The synthetic measure of entrepreneurship was correlated with the measure of development.
\end{abstract}

Key words: entrepreneurship, development, rural communes, synthetic measure.

JEL Classification: P25, R11, R12

\section{Introduction}

Despite the efforts to reduce development disparities between communes, powiats and voivodships, delays in some communes, especially rural voivodships of eastern Poland, are still very visible. Overcoming them requires, among others significantly accelerate the development of entrepreneurship. Therefore it is necessary to recognize the current situation regarding the level of entrepreneurship development in rural communes and to identify trends and regularities governing changes taking place in this area.

Entrepreneurship is an organized process of activities focused in given conditions on the use of an idea to achieve benefits on the market. Entrepreneurship is a way of acting; it consists in the tendency to take new, risky and unconventional ventures, and showing initiative in their search and implementation (Pawlik, 2016). Entrepreneurship is an interdisciplinary concept that is important for social and economic development. Issues related to entrepreneurship are taken up by representatives of many scientific disciplines, such as economics, management science, sociology, psychology, law, pedagogy, and ethics (Samitowska, 2009). They are characterized by multifacetedness and complexity. The variety of research approaches, data sources, methods used and, above all, the complexity and versatility of the topics discussed encourage research in this area.

The aim of the article is to assess the spatial diversity of entrepreneurship in the aspect of rural communes' development. The analysis of spatial diversity of entrepreneurship in rural communes was made using a synthetic measure. They were implemented in a system of 484 rural communes in eastern Poland (Program Operacyjny, Polska Wschodnia 2014-2020). Data from the Local Data Bank of the Central Statistical Office of 2009 and 2018 were used as source material.

\section{Method and materials used}

The authors' interest is rural communes of underdeveloped regions of eastern Poland. Among the elements conditioning the development of the region, S. Korenik identified, among others human capital, innovative facilities, entrepreneurship, transport and communication infrastructure, good living conditions and landscape values, quality of regional administration. S. Korenik (2011) also points to the process of thickening economic and social activity around active economic centres and the disappearance of this activity as they move away from them. He also emphasizes that disparities in the level of development are a natural phenomenon and that it is more important to support

\footnotetext{
Corresponding author:

${ }^{1}$ Jan Kochanowski University in Kielce, Poland.

E-mail: andrzej.pawlik@ujk.edu.pl

ORCID: https://orcid.org/0000-0003-2319-6707

${ }^{2}$ Jan Kochanowski University in Kielce, Poland.

E-mail: pawel.dziekanski@ujk.edu.pl

ORCID: https://orcid.org/0000-0003-4065-0043
} 
the progress of individual regions at their own pace adapted to their capabilities than to level the differences between regions at all costs. A. Klasik and F. Kuźnik (2001) define regional development as the sustainable growth of three elements: the economic potential of regions, their competitive strength and the level and quality of life of residents. The essence of regional development is to ensure cohesion is understood functionally and occurring in its three dimensions: economic, social, and territorial.

The endogenous potential of the individual also has an impact on local development. The diversified economic structure of the individual creates a peculiar development climate in which the conditions for starting business activity (entrepreneurship) arise. Endogenous territorial capital reveals the specificity of the place and its elements as well as the strategic value in market competition. According to T. Markowski (2011), it is generated external benefits, available as a result of user interaction within the region. It also causes diversity in the level of socio-economic development of local government units (Heffner, 2002).

E. Skawińska (2009) writes that entrepreneurship plays an important role in the efficient allocation of existing resources as well as the creation of new and more perfect ones. A. Klasik (2006) indicates that entrepreneurship as a determinant of sustainable development is the basis for the prosperity of regional economies and their communities. Entrepreneurshiprelated issues are multi-faceted and complex.
In the analysis of spatial diversity of entrepreneurship and development of rural communes in eastern Poland, synthetic measure based on the TOPSIS method was used. The synthetic analysis was carried out in the following stages:

I. The stimulant and destimulant sets were determined.

The description of the set can be presented in the form of an observation matrix $x_{i j}$ of the form:

$$
x_{i j}=\left[\begin{array}{cccc}
x_{11} & x_{12} & \ldots & x_{1 m} \\
x_{21} & x_{22} & \ldots & x_{2 m} \\
\ldots & \ldots & \ldots & \ldots \\
x_{n 1} & x_{n 2} & \ldots & x_{n m}
\end{array}\right]
$$

where $x i j$ denotes the values of the $j$-th feature for the i-th object $(i=1,2, \ldots, n ; j=1,2, \ldots, m)$.

From the set of variables, those with low spatial variability (coefficient of variation smaller than 0.10 ) and high correlation of variables (inverse correlation matrix) were removed. According to A. Raspberry, a large value of the correlation coefficient results in the duplication of information about the analysed phenomenon and may lead to incorrect conclusions (Malina, 2004). The set of variables selected for analysis is presented in Table 1.

II. The destimulant was replaced with a stimulant, counting its inverse by formula

$$
x_{i j}=\frac{1}{x_{i j}}
$$

Table 1

List of variables selected for analysis

\begin{tabular}{|l|c|c|}
\hline \multicolumn{1}{|c|}{ Variables } & Unit & S/D \\
\hline Entrepreneurial potential & & person \\
\hline Entities entered in the REGON register per 1000 population & person & S \\
\hline Units newly registered in the REGON register per 1000 population & person & D \\
\hline Units removed from the REGON register per 1000 population & person & S \\
\hline Natural persons conducting economic activity per 1000 population & & \\
\hline \multicolumn{1}{|c|}{ Development potential } & person & S \\
\hline Change in population per 1000 inhabitants & person & S \\
\hline Population Growth per 1000 inhabitants & person & S \\
\hline Migration rate per 1000 inhabitants & person & D \\
\hline Registered unemployed persons & person & S \\
\hline Employed persons in communes & \% & D \\
\hline Demographic dependency ratio for the elderly & person & S \\
\hline Apartments per 1000 inhabitants & person & S \\
\hline Population per 1 library (including library points) & person & S \\
\hline Population using the sewage network & person & S \\
\hline Population using the water supply network (person) & person & S \\
\hline Entities entered in the register per 1000 population; entrepreneurship rate & person & S \\
\hline Natural persons conducting economic activity per 1000 population; entrepreneurial activity rate & person & S \\
\hline Foundations, associations and social organizations per 1,000 inhabitants; social involvement & \% & S \\
\hline Own income / total income & \% & S \\
\hline Investment expenses / total expenses & \\
\hline
\end{tabular}

S - stimulant; D - destimulant

Source: own study based on BDL CSO data 
III. The stimulants obtained were subjected to the procedure of zeroed unitarisation using the following formula:

for stimulants

$$
z_{i j}=\frac{\mathrm{x}_{i j}-\min _{i} \mathrm{x}_{i j}}{\max _{i} \mathrm{x}_{i j}-\min _{i} x_{i j}} \text { when } x_{i} \in S
$$

where $S$ is stimulant, $i=1,2 \ldots n ; j=1,2 \ldots n, x_{i j}$ means the value of the $j$-th feature for the examined unit, $\max$ - the maximum value of the $j$-th feature, min is the minimum value of the $j$-th feature (Kukuła, 2000). As a result of the transformations, a matrix of uniformized variable values was obtained $z_{i j}$ :

$$
z_{i j}=\left[\begin{array}{cccc}
z_{11} & z_{12} & \ldots & z_{1 m} \\
z_{21} & z_{22} & \ldots & z_{2 m} \\
\ldots & \ldots & \ldots & \ldots \\
z_{n 1} & z_{n 2} & \ldots & z_{n m}
\end{array}\right]
$$

where $z_{i j}$ is the unified value of $x_{i j}$.

IV. Then the measures of entrepreneurship and economic development based on the TOPSIS method were counted. As part of the adopted method, Euclidean distances of individual objects from the pattern $(=1)$ and anti-pattern $(=0)$ were determined according to the following formulas:

$$
\begin{aligned}
& d_{i}^{+}=\sqrt{\frac{1}{n} \sum_{j=1}^{m}\left(z_{i j}-z_{j}^{+}\right)^{2}} \\
& d_{i}^{-}=\sqrt{\frac{1}{n} \sum_{j=1}^{m}\left(z_{i j}-z_{j}^{-}\right)^{2}}
\end{aligned}
$$

where $\mathrm{n}$ is the number of variables that make up the pattern or anti-pattern, $z_{i j}$ means the unified value of the $j$-th feature for the unit being tested, $z_{j}^{+}, z_{j}^{-}$means the pattern or anti-pattern (Wójcik-Leń, et al., 2019; Pietrzak, 2016).

The synthetic measure according to the TOPSIS method was determined for individual units on the basis of the formula:

$$
q_{i}=\frac{d_{i}^{-}}{d_{i}^{-}+d_{i}^{+}}, \text {where } 0 \leq q_{i} \leq 1, i=1,2, \ldots, n ;
$$

where $q i \in[0 ; 1]$; $\max i\{q i\}$ is the best object; $\min i$ $\{q i\}$ is the worst object, $d_{i}^{-}$means the distance of the object from the anti-pattern (from 0$), d_{i}^{+}$means the distance of the object from the pattern (from 1). A higher value of measure indicates a better situation of the individual in the studied area (Hwang, Yoon, 1981; Balli, Korukoglu, 2009).

V. In the last stage, the examined area of rural communes in eastern Poland was divided into 4 quartile groups. The size of the indicator in the first group means a better unit, and in the last one the weakest. The mutual compliance of the results obtained was also verified based on the correlation coefficient. A scatter chart with an adjustment line for synthetic measures is also presented (Zeliaś, Malina, 1997; Dziekański, 2019; Pawlik, Dziekański, 2020).

\section{Discussion and research results}

Regions compete by the level of their investment attractiveness in attracting investments, as well as creating opportunities for socio-economic development and an increase in the standard of living of residents (Boschma, 2006). Disproportions in the development of regions may cause its marginalization. It is manifested in a decrease in entrepreneurship and the concentration of negative socio-economic phenomena, such as unemployment, impoverishment of the population, outflow of population, social pathologies (Krajowa Strategia Rozwoju Regionalnego 2010-2020; Stawasz 2007). Analysing the literature on the subject, we notice problems and difficulties arising in research in the field of identification and measurement of factors affecting the development of entrepreneurship in marginalized areas.

Entrepreneurship activity varies regionally, which results from the structural features of the regions (location rents) and endogenous factors occurring in their area. The factors that create a kind of field of forces generating or blocking the entrepreneurship of the region include: demographic characteristics of the region, regional labour market, quality of human capital, housing resources and their standard, infrastructure equipment (Huczek, 2016).

According to the theory of location (J.H. von Tünen, A. Weber, W. Christaller and A. Lösch), the development of the territory is decided by enterprises choosing or not a given region as the place of their functioning (Stawasz, 2000). The development of entrepreneurship is one of the tools to eliminate economic and civilization inequalities. Enterprises contribute to the economic development of regions, increase the ability to produce goods and services and are one of the pillars of the development of modern economies. They stimulate regional development through a more complete and at the same time comprehensive effective use of regional resources (Glinka, Gudkova, 2011). Entrepreneurship can be recognized as a permanent base of the regional economy. D. Valliere and R. Peterson (2009) recognized that entrepreneurship influenced the development of regions through the efficient use of available resources, innovative activities as well as growing competition.

Development is a multidimensional process that involves transforming individuals' factors and resources into goods and services for the local economy. The multidimensionality of the development process is demonstrated by the directions of municipalities as a local multidimensional system of interdependent and related economic, social, infrastructural and natural 
factors, as well as benefits obtained in the spatial, social, economic aspect, etc. These activities are usually focused on goals, among which should there be distinguished long-term development, increase in income of residents and the budget, development of entrepreneurship. Development is controlled and modified by local authorities using endogenous factors: finance, labour, technology, information and others (Rynio, 2010). The development factors are changing over time, so they need to be analysed continuously (Stimson, Stough, Nijkamp, 2011).

Development is the entirety of the socio-economic changes taking place in a given territory. It is perceived as an economic process involving the transformation of external and internal factors and regional resources into goods and services (Kosiedowski, 2001). It ensures a sustainable increase in the standard of living of the inhabitants and the economic potential. Among others, it includes economic potential and structure, natural environment, spatial and infrastructural development, and growth of entrepreneurship (Holuj, Korecki, 2008).

The enterprise employs people, stimulates the creation of new companies that will be associated with it, which affects the activity of the local population. Entrepreneurship is the process of creating something new and valuable, assuming personal financial, mental and social risk, as well as assuming monetary compensation and personal satisfaction (Hisrich, Pater, 1992).

Assessment of the operation of municipalities (in terms of development or support for entrepreneurship), in the conditions of network economy, depends on systemic solutions enabling independence in undertaking activities, financial resources, the natural environment, infrastructure, entrepreneurship and cooperation skills. Recently, the complexity of phenomena is increasing, as well as their uncertainty, which results in the increasing dependence of the quality of decisions made by human on the quality of information process (Jajuga, 1993). The analysis and assessment of the unit's endogenous resources not only enables the assessment of the budget structure itself, but also indirectly provides information on the state of the local economy (Satoła, 2015).

Financial resources are an element necessary for the effective execution of the units' objectives in terms of current or development tasks. There is a feedback between socioeconomic and financial variables (Dennis, 2004; Standar, 2017). Assessment of the financial situation of municipalities allows to determine not only the efficiency of these units, i.e. the ability to meet their obligations, but also the possibility of raising the quality standard of services they provide to local communities (Douglas, Gaddie, 2002). Finances allow for a comprehensive assessment of the operation of a local government unit and its development opportunities.
Natural conditions (natural environment) are a primary and at the same time passive growth factor. The very fact of the existence of favourable natural conditions in a given area does not prejudge the structure of its economy or the level of its development. The degree and directions of use of natural resources depend on human activities. Natural resources include: natural resources, natural forces and environmental qualities that determine the quality of human life (Fierla, 1998).

In 2018, the TOPSIS measure of entrepreneurship ranged from 0.07 (Nowy Dwór, Podlaskie Voivodship, the weakest unit) to 0.63 (Cisna, Podkarpackie Province, the best unit). In 2009, from 0.05 (Podlasie, Przytuły (2), Milejczyce (2), Nowy Dwór (2)) to 0.57 (Podkarpackie, Lutowiska (2)). In contrast, the measure of development in 2018 ranged from 0.23 (Nozdrzec, Podkarpackie Voivodship) to 0.62 (Stawiguda, Warmińsko-Mazurskie Voivodship), and in 2009 from 0.22 (Lubelskie, Drelów (2)) to 0.54 (Stawiguda (2), Warmińsko-Mazurskie Voivodship). The diversity of values adopted by the measure of entrepreneurship is 0.56 and development 0.39 . This indicates a smaller diversity of rural communes in eastern Poland in terms of development. In the aspect of entrepreneurship, the following communes were: Cisna, Stawiguda, Konopnica, Juchnowiec Kościelny, Miedziana Góra, and in the aspect of development, the following communes were: Stawiguda, Lutowiska, Puchaczów, Juchnowiec Kościelny, and Sitkówka-Nowiny. Figure 1 presents the spatial diversity of development potential and entrepreneurship of Eastern Poland communes.

In group I (best), according to the measure of entrepreneurship, there were communes from the following voivodships: Lubelskie - 43 (26.06\% of communes of the voivodship), Podkarpackie 27 (25\%), Podlasie - 9 (11.54\%), Świętokrzyskie $30(45.45 \%)$ and Warmińsko-Mazurskie-22 (32.83\%). The increase in range indicates an increase in the diversity of units in the area under study. In group I, by measure of development, the following communes were found: Lubelskie 27 (15.15\%), Podkarpackie 36 (33.33\%), Podlasie 23 (29.49\%), Świętokrzyskie 23 (34.84\%) and Warmińsko-Mazurskie 28 (41.79\%). The reduction in range indicates a decrease in the diversity of units in the area under study (see Table 2).

An analysis of the dispersion of the measure of synthetic entrepreneurship and the measure of development of rural communes in eastern Poland in 2009 and 2018 indicates a slight increase in diversity. Outstanding units in all voivodships: Świętokrzyskie, Podkarpackie, Lubelskie, Podlasie and WarmińskoMazurskie Voivodship.

The measures of diversity in entrepreneurship in 2018 compared to 2009 show an increase in standard deviation (0.06-0.07), a decrease in the classic 

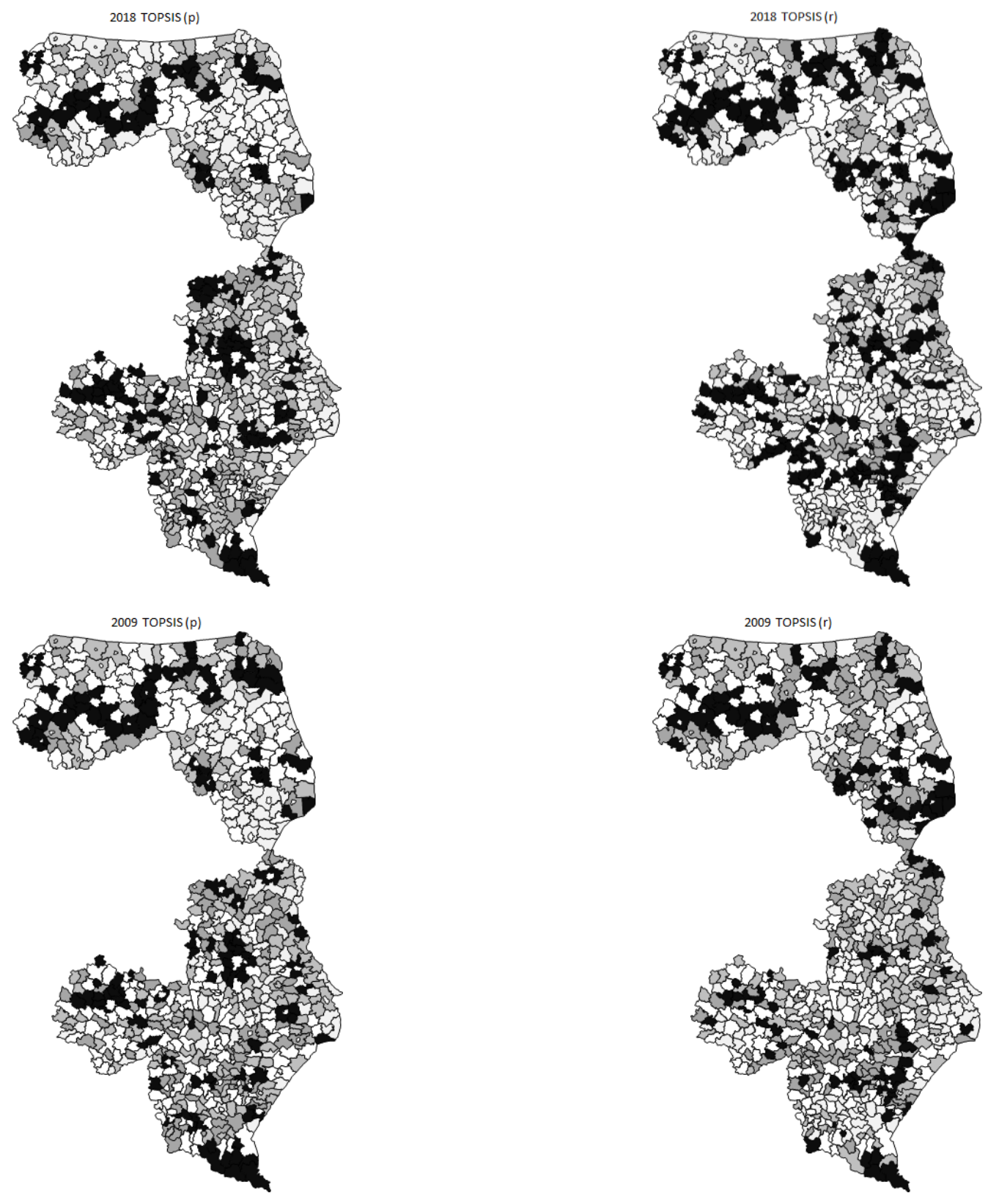

Gr I

Gr III

Gr IV

Figure 1. Groups of synthetic measures of entrepreneurship and development of rural communes in eastern Poland in 2009 and 2018

TOPSIS (p) entrepreneurship and TOPSIS ( $\mathrm{r}$ ) development potential; the first, second and third quartiles were used as the thresholds for the groups; white means the urban and urban-rural communes not covered by the survey, black means the best units, light grey presents the weakest units

Source: own study based on BDL CSO data

coefficient of variation $(0.42-0.33)$ and an increase in the range $(0.52-0.56)$. In the case of development, the measures of differentiation indicate - the standard deviation stability (0.05-0.05), a decrease in the classic coefficient of variation (0.14-0.13), an increase in the range (0.32-0.39). Measures of differentiation indicate slight changes in the studied area and a similar response of individuals to processes in the economy (Table 3 ).
The Pearson correlation coefficient between the values of the synthetic entrepreneurship measure in 2018 compared to 2009 was 0.848 ; for the synthetic measure of development it was 0.869 and 0.525 and 0.549 respectively. Therefore, it can be assumed that the spatial diversity of the studied area was quite stable, and the units responded similarly to changes in the economy (see Figure 3). 
Table 2

Quartile groups according to the measure of entrepreneurship and measure of development as well as belonging of communes to voivodships

\begin{tabular}{|l|c|c|c|c|c|c|c|c|c|}
\hline \multicolumn{2}{|c|}{ TOPSIS entrepreneurship } & \multicolumn{3}{c|}{2009} & \multicolumn{3}{c|}{2018} \\
\hline Voivodship / Group & I & II & III & IV & I & II & III & IV & \\
\hline Lubelskie & 165 & 34 & 39 & 55 & 37 & 43 & 29 & 62 & 31 \\
\hline Podkarpackie & 108 & 32 & 37 & 32 & 7 & 27 & 41 & 31 & 9 \\
\hline Podlaskie & 78 & 15 & 14 & 20 & 29 & 9 & 13 & 23 & 33 \\
\hline Świętokrzyskie & 66 & 21 & 22 & 15 & 8 & 30 & 16 & 18 & 2 \\
\hline Warmińsko-Mazurskie & 67 & 27 & 16 & 16 & 8 & 22 & 16 & 12 & 17 \\
\hline Number of units & 484 & 129 & 128 & 138 & 89 & 131 & 115 & 146 & 92 \\
\hline Average & 0.23 & 0.15 & 0.12 & 0.09 & 0.31 & 0.22 & 0.19 & 0.14 \\
\hline Range & \multicolumn{7}{|c|}{0.14} & & \multicolumn{5}{c|}{0.17} \\
\hline
\end{tabular}

\begin{tabular}{|l|c|c|c|c|c|c|c|c|c|}
\hline \multicolumn{2}{|c|}{ TOPSIS development } & \multicolumn{9}{c|}{2009} & \multicolumn{3}{c|}{2018} \\
\hline Voivodship / Group & I & II & III & IV & I & II & III & IV & \\
\hline Lubelskie & 165 & 23 & 46 & 54 & 42 & 27 & 51 & 29 & 58 \\
\hline Podkarpackie & 108 & 33 & 33 & 18 & 24 & 36 & 33 & 13 & 26 \\
\hline Podlaskie & 78 & 34 & 20 & 16 & 8 & 23 & 28 & 10 & 17 \\
\hline Świętokrzyskie & 66 & 24 & 14 & 17 & 11 & 23 & 24 & 9 & 10 \\
\hline Warmińsko-Mazurskie & 67 & 29 & 22 & 15 & 1 & 28 & 10 & 19 & 10 \\
\hline Number of units & 484 & 143 & 135 & 120 & 86 & 137 & 146 & 80 & 121 \\
\hline Average & 0.39 & 0.34 & 0.31 & 0.27 & 0.42 & 0.37 & 0.35 & 0.31 \\
\hline Range & \multicolumn{7}{|c|}{0.12} & & \multicolumn{2}{c|}{0.11} \\
\hline
\end{tabular}

Source: own study based on BDL CSO data

The correlation coefficient between the values of the measure of synthetic entrepreneurship and development was 0.539 , which indicated the stability of spatial diversity in the examined aspect. Gunnar Myrdal in the theory of cumulative causation referring to the analysis of the interdependence of social, economic and institutional phenomena has proved that every element interacting with another element affects its behaviour, and at the same time is modified by the reaction of that element.

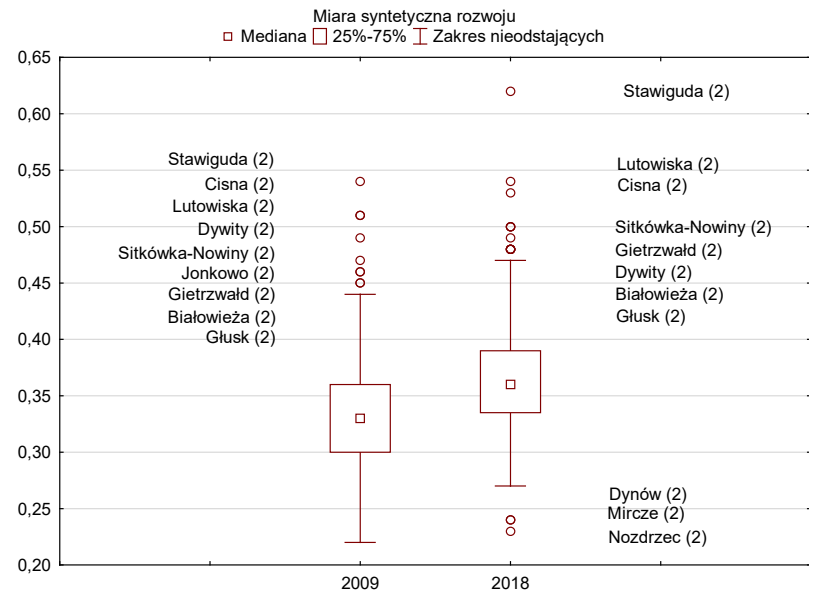

The synthetic measure of entrepreneurship is correlated with the measure of development and the measure of other variables affecting the activities of rural communes (see Table 4). The correlation between the measures of entrepreneurship and development and the variables of socio-economic conditions are presented in Table 5. The coefficients inform about the possibility of generating income from own sources. This can be an indicator of sustainable development and allows for more flexible

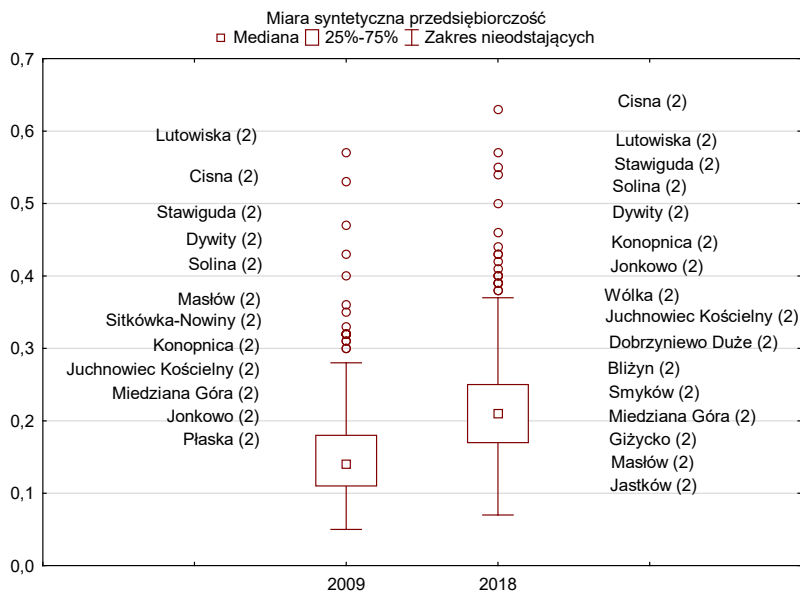

Figure 2. Scattering of synthetic measures of entrepreneurship and development of communes of Eastern Poland voivodships in 2009 and 2018

Source: own study based on BDL CSO data 
Vol. 7 No. 2, 2021

Table 3

Differentiation of synthetic measures - entrepreneurship and development of rural communes in eastern Poland in 2009 and 2018

\begin{tabular}{|l|c|c|c|c|}
\hline \multirow{2}{*}{} & \multicolumn{2}{|c|}{ Entrepreneurship measure } & \multicolumn{3}{|c|}{ Development measure } \\
\cline { 2 - 5 } & 2009 & 2018 & 2009 & 2018 \\
\hline average & 0.15 & 0.22 & 0.33 & 0.36 \\
\hline median & 0.14 & 0.21 & 0.33 & 0.36 \\
\hline standard deviation & 0.06 & 0.07 & 0.05 & 0.05 \\
\hline quarter (quartile) deviation & 0.15 & 0.21 & 0.33 & 0.36 \\
\hline classic coefficient of variation & 0.42 & 0.33 & 0.14 & 0.13 \\
\hline positional coefficient of variation & 1.04 & 1.00 & 1.00 & 0.01 \\
\hline min. & 0.05 & 0.07 & 0.52 & 0.23 \\
\hline max & 0.57 & 0.63 & 0.32 & 0.32 \\
\hline range & 0.52 & 0.56 & 0.30 & 0.34 \\
\hline quatrile 1 & 0.11 & 0.17 & 0.33 & 0.36 \\
\hline quatrile 2 & 0.14 & 0.21 & 0.36 & 0.39 \\
\hline quatrile 3 & 0.18 & 0.25 & 0.06 & 0.05 \\
\hline quartile range & 0.07 & 0.08 & 0.58 & 0.71 \\
\hline skewness & 2.08 & 1.61 & & \\
\hline
\end{tabular}

Source: own study based on BDL CSO data
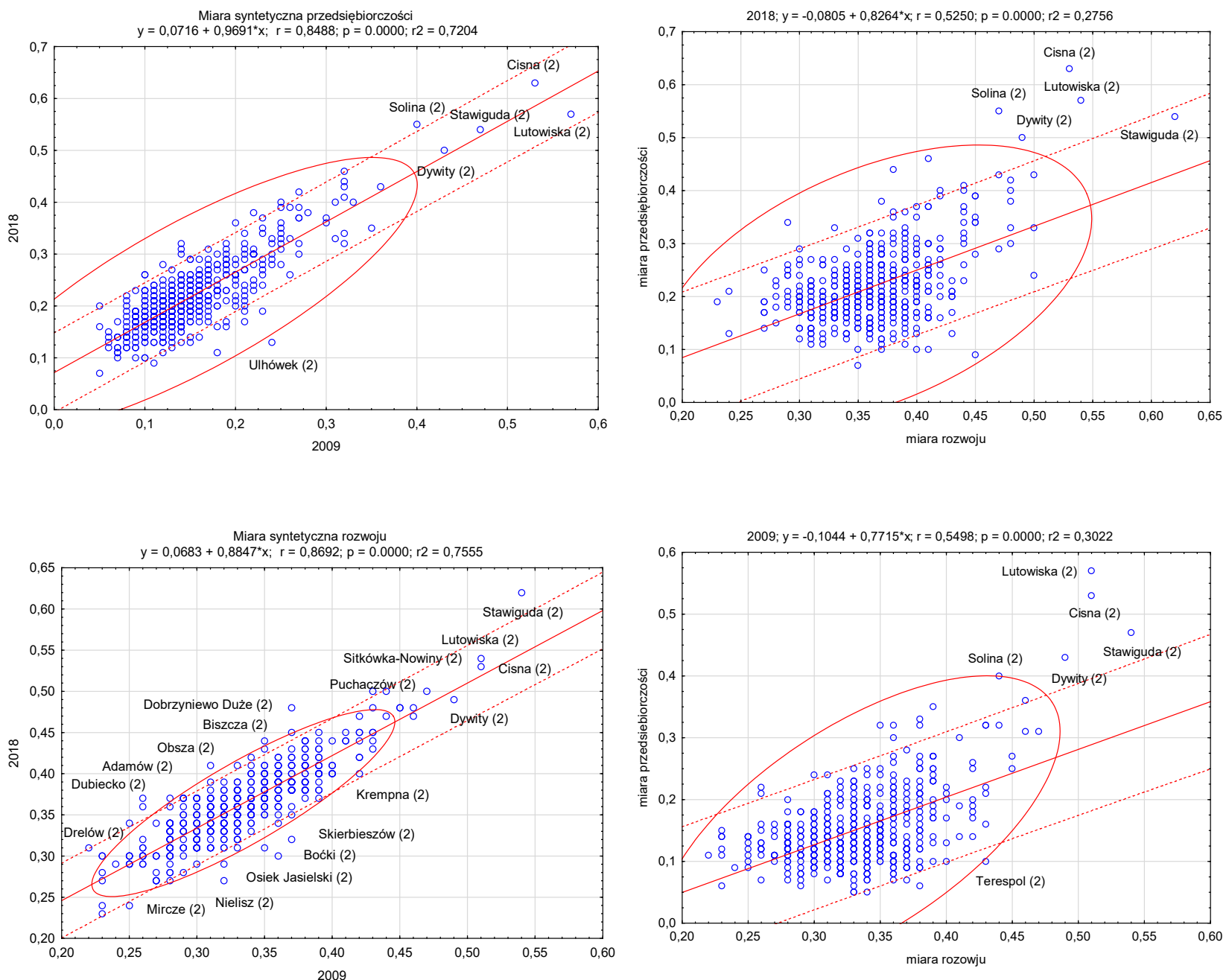

Figure 3. A scatter chart with an adjustment line of the synthetic measures of entrepreneurship and development of rural communes in the voivodships of eastern Poland in 2009 and 2018 (year-to-year measure)

Source: own study based on BDL CSO data 
Table 4

Correlation between measures of entrepreneurship and development and areas of operation of rural communes

\begin{tabular}{|l|c|c|}
\hline & TOPSIS entrepreneurship & TOPSIS development \\
\hline TOPSIS entrepreneurship & 1 & 0.5392 \\
\hline TOPSIS development & 0.5392 & 0.3229 \\
\hline TOPSIS finance & 0.298 & 0.7636 \\
\hline TOPSIS infrastructure & 0.0816 & 0.4403 \\
\hline TOPSIS demographics & 0.4731 & -0.1056 \\
\hline TOPSIS environment & -0.2061 & 0.0881 \\
\hline TOPSIS budget solvency & 0.0651 & 0.4249 \\
\hline TOPSIS financial independence & 0.3205 & 1 \\
\hline
\end{tabular}

Linear correlation coefficients for observations from sample 1-4840;

Critical value (at a 5\% bilateral critical area) $=0.0282$ for $\mathrm{n}=4840$

Source: own study based on BDL CSO data

Table 5

Correlation between measures of entrepreneurship and development and variables of socio-economic conditions

\begin{tabular}{|l|c|c|}
\hline & TOPSIS entrepreneurship & TOPSIS development \\
\hline Own income & 0.4486 & 0.5524 \\
\hline Share in PIT and CIT income & 0.5972 & 0.4151 \\
\hline Transfer income from the state budget (subsidies, subventions) & -0.4145 & -0.5468 \\
\hline Income from local taxes & 0.2071 & 0.3602 \\
\hline Investment expenditures & 0.0599 & 0.2221 \\
\hline Entities entered into REGON & 0.9424 & 0.5668 \\
\hline Self-employed persons & 0.9443 & 0.5285 \\
\hline Entities employing up to 9 employees & 0.9421 & 0.5606 \\
\hline Entities employing od 10 do 49 employees & 0.3216 & 0.2591 \\
\hline Entities employing from 50 to 249 employees & 0.3041 & 0.3122 \\
\hline Migration rate & 0.4558 & 0.3791 \\
\hline Employed persons in communes & 0.2417 & 0.3484 \\
\hline Unemployed & -0.0593 & -0.1676 \\
\hline
\end{tabular}

Linear correlation coefficients for observations from sample 1-4840;

Critical value (at a 5\% bilateral critical area) $=0.0282$ for $\mathrm{n}=4840$

Source: own study based on BDL CSO data

spending. Rural communes are dependent on transfer revenues transferred from the state budget. Although this situation guarantees financial security for local governments, it may also discourage them from pursuing an active development policy. Low financial independence can therefore be a significant barrier to future development.

To assess the impact of the areas of operation of rural communes of eastern Poland on the spatial diversity of the entrepreneurship measure, a regression model describing the dependence of variables has been estimated taking the form:

$\mathrm{F}$ (entrepreneurship) $=\sum$ (TOPSIS development,

TOPSIS finance, TOPSIS infrastructure,

TOPSIS demographic, TOPSIS environment).

The regression analysis of the measure of synthetic entrepreneurship and endogenous potentials of communes indicates that the presented regression model allows to explain $\mathrm{R}=$
0.591 variable variations. The statistics values $\mathrm{F}$ (5.4834) 1402.487 and the corresponding probability level $\mathrm{p}$ mean that all parameters are statistically significant. Further increasing the multidimensionality of the model would cause a slight increase in the value of $\mathrm{R}^{2}=0.591$ (see Table 6 ). The model could include statistically insignificant variables. Adjusted coefficient of determination did not reach $60 \%$. The optimal value is considered exceeding the 95\% determination threshold. The model does not optimally explain the level of entrepreneurship in rural communes. This indicates that the interpretative value of this model turns out to be unsatisfactory.

The concept of "potential" is used in various fields of science, and in economic sciences its meaning is very important, because it means the economic category determining the effectiveness and efficiency of any activity. It comes from the Latin "potential", which means possibility, power. It derives from Aristotle, who made a distinction between what really is and what has 
Table 6

Regression of synthetic measure of entrepreneurship and areas of operation of rural communes in eastern Poland

\begin{tabular}{|l|c|c|c|c|}
\hline & Coefficient & Standard error & t-Student's & $\mathrm{p}$-value \\
\hline Constant & -0.0425856 & 0.0114727 & -3.712 & 0.0002 \\
\hline TOPSIS development & 2.42872 & 0.0391340 & 62.06 & $<0.0001$ \\
\hline TOPSIS finance & -0.291085 & 0.0422895 & -6.883 & $<0.0001$ \\
\hline TOPSIS infrastructure & -0.814470 & 0.0159171 & -51.17 & $<0.0001$ \\
\hline TOPSIS demographics & -0.521290 & 0.0248633 & -20.97 & $<0.0001$ \\
\hline TOPSIS environment & -0.0996662 & 0.0130997 & -7.608 & $<0.0001$ \\
\hline
\end{tabular}

\begin{tabular}{|l|c|l|c|}
\hline Arithmetic mean of the dependent variable & 0.180864 & Standard deviation of the dependent variable & 0.070946 \\
\hline Sum of residual squares & 9.938670 & Residual standard error & 0.045343 \\
\hline Determining coefficient R- square & 0.591945 & Corrected R-square & 0.591523 \\
\hline F(5.4834) & 1402.487 & P-value for the F test & 0.000000 \\
\hline Logarithm of credibility & 8107.871 & Akaike information criteria & -16203.74 \\
\hline Bayesian, Schwarz information criterion & -16164.83 & Hannan-Quinn criterion & -16190.08 \\
\hline
\end{tabular}

Observations 1-4840 used; dependent variable TOPSIS entrepreneurship

Source: own study based on BDL CSO data

not existed yet, but can occur under certain conditions or with some change (Pawlik, 2014).

The economic potential of the commune is built, among others, by occupational activity of inhabitants, local labour market, entrepreneurship, infrastructure, state of the natural environment. High economic potential increases living standards, production, better social situation, and greater public security (Krakowiak-Bal, 2006). The commune's potential, resulting from a combination of local conditions, determines its possibilities and development directions (Pomianek, 2016).

Another regression model describing the relationship between the entrepreneurship measure and the changing socioeconomic conditions takes the form:
$\mathrm{F}$ (entrepreneurship) $=\sum$ (Own revenue, Transfer income from the state budget

(subsidies, subventions), Entities entered in the REGON, Natural persons conducting economic activity, Balance of migration).

The regression analysis of the measure of the synthetic financial situation and endogenous potentials of communes indicates that the presented regression model allows explaining $\mathrm{R}=0.899$ variations of variables. The statistics values $\mathrm{F}$ (5.4834) 8700.485 and the corresponding probability level $\mathrm{p}$ mean that all parameters are statistically significant. Further increasing the multidimensionality of the model would cause a slight increase in $\mathrm{R}^{2}=0.899$ (Table 7).

\section{Table 7}

Regression of synthetic measure of entrepreneurship and areas of operation of rural communes in eastern Poland

\begin{tabular}{|l|c|c|c|c|}
\hline Name & Coefficient & Standard error & t-Student's & $\mathrm{p}$-value \\
\hline Constant & -0.00541195 & 0.00467655 & -1.157 & 0.2472 \\
\hline Own income & -0.0243611 & 0.00538722 & -4.522 & $<0.0001$ \\
\hline Transfer income from the state budget (subsidies, subventions) & -0.0158850 & 0.00493422 & -3.219 & 0.0013 \\
\hline Entities entered into REGON & 0.00192312 & 0.000105776 & 18.18 & $<0.0001$ \\
\hline Self-employed persons & 0.00235168 & 0.000115731 & 20.32 & $<0.0001$ \\
\hline Net migration rate & 0.000333932 & $6.68099 \mathrm{e}-05$ & 4.998 & $<0.0001$ \\
\hline
\end{tabular}

\begin{tabular}{|l|c|l|c|}
\hline Arithmetic mean of the dependent variable & 0.180864 & Standard deviation of the dependent variable & 0.070946 \\
\hline Sum of residual squares & 2.435799 & Residual standard error & 0.022447 \\
\hline Determining coefficient R- square & 0.899993 & Corrected R-square & 0.899889 \\
\hline F(5.4834) & 8700.485 & P-value for the F test & 0.000000 \\
\hline Logarithm of credibility & 11510.77 & Akaike information criteria & -23009.55 \\
\hline Bayesian, Schwarz information criterion & -22970.64 & Hannan-Quinn criterion & -22995.89 \\
\hline
\end{tabular}

Observations 1-4840 used; dependent variable TOPSIS entrepreneurship

Source: own study based on BDL CSO data 


\section{Conclusions}

Entrepreneurship, which is one of the most important endogenous resources, becomes the basis for the socio-economic development of rural communes in eastern Poland in the conditions of transformation and the adopted market economy. Entrepreneurship contributes to the establishment of new business entities, directly affecting the improvement of the level and quality of life in municipalities and the increase in the well-being of society. Sources of municipal disproportions result from the spatial diversity of, among others, natural conditions, transport accessibility, location of large settlement centers, close location of enterprises of the same branch, concentration of plants of various industries and services, access to investment capital, equipment with institutional infrastructure, level of entrepreneurship, ability to absorb innovation, access to knowledge and technological development.

In 2018, the TOPSIS method for measuring entrepreneurship ranged from 0.07 to 0.63 and the development measure from 0.23 to 0.62 . The range of values adopted by the measure of entrepreneurship was 0.56 and development 0.39 . This confirms the smaller diversity of rural communes in eastern Poland in the aspect of development, and greater in the aspect of entrepreneurship. At the same time, the synthetic measure of entrepreneurship was correlated with the measure of development. The level of entrepreneurial activity is varied. Owned structural features of communes and endogenous factors occurring in their area cause that they differ in the scale of entrepreneurial activity. Factors generating a kind of field of generating forces or blocking entrepreneurship of communes include: demographics of the region, situation on the regional labor market, vitality of the economic structure of the region, quality of human capital, prestige of entrepreneurs, housing resources and their standard, infrastructure equipment. Therefore, rural communes of Eastern Poland should consider entrepreneurship as the basis for their development.

The results of the study give municipalities the opportunity to compare the situation in terms of entrepreneurship and development with the situation of neighbouring municipalities or municipalities with similar economic and social conditions. The conclusions drawn on this basis may allow local authorities to set directions for optimizing endogenous potential.

\section{References:}

Balli S., Korukoglu S. (2009), Operating System Selecting Using Fuzzy AHP and TOPSIS Method, Mathematical and Computational Applications (14)2, 119-130.

Boschma R. A. (2006), Competitiveness of Regions from an Evolutionary Perspective [In:] R. Martin, M. Kitson, P. Tyler (ed.), Regional Competitiveness, Routledge, London-New York, 14.

Capello R., Nijkamp P. (2011), Regional Growth and Development Theories Revisited, [In:] R. Stimson, R. R. Stough, P. Nijkamp (ed.), Endogenous Regional Development, chapter 15, Edward Elgar Publishing.

Dennis L. (2004), Determinants of Financial Condition: A Study of US Cities, Orlando, FL: University of Central Florida, 43-45.

Douglas J. W., Gaddie R. K. (2002), State rainy day funds and fiscal crises: Rainy day funds and the 1990-1991 recession revisited, Public Budgeting \& Finance, t. 22, https:// doi: 10.1111/1540-5850.00063

Dziekański P. (2019), The financial situation of cities with poviat rights in eastern Poland vs. Diversification of development potential, Biblioteka Regionalisty (Regional Journal), NR 19 (2019), 50-65.

Fierla I. (1998), Struktura przestrzenna gospodarki, [In:] Geografia gospodarcza Polski, ed. I. Fierla, Wyd. Naukowe PWE, Warszawa, 9-29.

Glinka B., Gudkova S. (2011), Przedsiębiorczość, Wolters Kluwer, Warszawa.

Heffner K. (2002), Czynniki osadnicze wplywajace na potencjat rozwojowy obszarów wiejskich, [In:] Wiejskie obszary kumulacji barier rozwojowych, Kłodziński M. (ed.), IRWiR PAN, Warszawa.

Hisrich R. D., Pater M. P. (1992), Entrepreneurship. Starting, developing and managing a new enterprise, IRWING, Boston, 10.

Hołuj A., Korecki D. (2008), Uwarunkowania rozwoju regionalnego w Polsce, Zeszyty Naukowe Wyższej Szkoły Ekonomicznej w Bochni, nr 7, 23.

Huczek M. (2016), Przedsiębiorczość i konkurencyjność w rozwoju regionalnym, ZN WSH Zarządzanie, 3, 247-257. Hwang C. L., Yoon K. (1981), Multiple attribute decision making. Methods and applications, Springer, Berlin [for:] A. Bieniasz, Z. Gołaś, A. Łuczak (2013), Zróżnicowanie kondycji finansowej gospodarstw rolnych wyspecjalizowanych w chowie owiec i kóz w krajach Unii Europejskiej, Roczniki Ekonomii Rolnictwa i Rozwoju Obszarów Wiejskich, T. 100, z. 1. Jajuga K. (1993), Statystyczna analiza wielowymiarowa, Wyd. Naukowe PWN, Warszawa, 9.

Klasik A. (2006), Przedsiębiorczość i konkurencyjność a rozwój regionalny, Wyd. AE w Katowicach, Katowice, 20.

Klasik A., Kuźnik F. (2001), Konkurencyjny rozwój regionów w Europie, [In:] Konkurencyjność miast i regionów, ed. Z. Szymla, AE w Krakowie, Kraków, 27.

Korenik S. (2011), Region ekonomiczny w nowych realiach spoteczno-gospodarczych, CeDeWu, Warszawa (Recenzja; Studia Regionalne i Lokalne Nr 1(47)/2012 ISSN 1509-4995). 
Kosiedowski W. (2001), Teoretyczne problemy rozwoju regionalnego, [In:] Zarządzanie rozwojem regionalnym i lokalnym, Problemy teorii i praktyki, TNOiK, Toruń, 29.

Krajowa Strategia Rozwoju Regionalnego 2010-2020 (2010), Regiony, miasta, obszary wiejskie, Ministerstwo Rozwoju Regionalnego, Warszawa, 17.

Krakowiak-Bal A. (2006), Potencjat gospodarczy gmin przygranicznych Polski poludniowej infrastruktura i ekologia terenów wiejskich, Nr 2/2/, PAN, Oddział w Krakowie, 149-158.

Kukuła K. (2000), Metoda unitaryzacji zerowanej, Wyd. Naukowe PWN, Warszawa, 47-48.

Malina A. (2004), Wielowymiarowa analiza przestrzennego zróżnicowania struktury gospodarki Polski wedtug województw, Wyd. Akademii Ekonomicznej w Krakowie, Kraków, 96-97.

Markowski T. (2011), Funkcjonowanie gospodarki przestrzennej - założenia budowy modelu zintegrowanego planowania i zarządzania rozwojem, Studia Polska Akademia Nauk. Komitet Przestrzennego Zagospodarowania Kraju CXXXIV (134), 25-44.

Motek P. (2006), Gospodarka finansowa samorządu terytorialnego w województwie wielkopolskim, Bogucki Wydawnictwo Naukowe, Poznań, 164-169.

Pawlik A. (2014), Dystans innowacyjny województw w roku 2016, Wyd. UJK, Kielce, 91.

Pawlik A. (red.) (2016), Przedsiębiorczość, Wyd. UJK, Kielce, 9.

Pawlik A., Dziekański P. (2020), Atrakcyjność miast i gmin województwa świętokrzyskiego, Uniwersytet Jana Kochanowskiego, UJK, Kielce.

Pietrzak M. B. (2016), The problem of the inclusion of spatial dependence within the TOPSIS Method, Montenegrin Journal of Economics, 12(3), pp. 69-86.

Polski Program Operacyjny, Polska Wschodnia 2014-2020. Available at: https://www.polskawschodnia.gov.pl/ media/1278/Program_Polska_Wschodnia_2014_2020.pdf (accessed on 02.02.2020).

Pomianek I. (2016), Charakterystyka potencjatu gospodarczego oraz przestrzennych zróżnicowań rozwojowych gmin wiejskich województwa lubelskiego, Acta Universitatis Lodziensis Folia Oeconomica, 4(323).

Rynio D. (2010), Rozwój regionu oparty na zasobach endogenicznych, Studia Zarządzania i Finansów Wyższej Szkoły Bankowej w Poznaniu, nr 1, 61-69.

Samitowska W. (2009), Ekonomiczne aspekty wspierania przedsiębiorczości przez samorzą terytorialny, [In:] B. Filipiak (ed.), Samorzad terytorialny w zintegrowanej Europie, Zesz. Nauk., nr 526, Ekonomiczne Problemy Usług, nr 29, Wyd. Naukowe Uniwersytetu Szczecińskiego, Szczecin.

Satoła Ł. (2015), Kondycja finansowa gmin w warunkach zmiennej koniunktury gospodarczej, Journal of Agribusiness and Rural Development, 1(35), 115-123.

Skawińska E. (2009), Kapitał społeczny w rozwoju regionu, [In:] W. Janasz, Innowacje w strategii rozwoju organizacji w Unii Europejskiej, Warszawa, 48.

Standar A. (2017), Ocena kondycji finansowej gmin oraz jej wybranych uwarunkowań na przykładzie województwa wielkopolskiego przy wykorzystaniu metody TOPSIS, Wieś i Rolnictwo, 2(175), 69-92.

Stawasz D. (2000), Współczesne uwarunkowania rozwoju polskich regionów, Wyd. UŁ, Łódź, 191.

Stawasz D. (2007), Rozwój regionalny ujęcie teoretyczne [In:] H. Skłodowski, E. Stawasz (ed.), Psychologiczne wyznaczniki efektywności poszukiwania pracy i samozatrudnienia $w$ regionach zmarginalizowanych, Wyd. UŁ, Łódź, 43-53.

Valliere D., Peterson R. (2009), Entrepreneurship and Economic Growth: Evidence from Emerging and Developed Countries, Entrepreneurship \& Regional Development, t. 25, no. 5 [For:] D. Miłek, I. Kantarek (2017), Przedsiębiorczość w rozwoju polskich regionów, Nierówności Społeczne a Wzrost Gospodarczy, nr 50(2).

Wójcik-Leń J., Leń P., Mika M., Kryszk H., Kotlarz P. (2019), Studies regarding correct selection of statistical methods for the needs of increasing the efficiency of identification of land for consolidation - A case study in Poland. Land Use Policy.

Zeliaś A., Malina A. (1997), O budowie taksonomicznej miary jakości życia. Syntetyczna miara rozwoju jest narzędziem statystycznej analizy porównawczej, Taksonomia, z. 4. 